\title{
Patterns of technical progress in the Brazilian economy, 1952-2008
}

\section{Adalmir Marquetti and Melody de Campos Soares Porsse}

ABSTRACT

This article analyses the pattern of technical change in the Brazilian economy between 1952 and 2008. A Marx-biased pattern of labour-saving and capital-using change predominated in the period under study. Three phases in the dynamism of technical change can be distinguished, however. The first, from 1952 to 1973, was highly dynamic. In the second, from 1973 to 1991, this dynamism lessened. Lastly, between 1991 and 2008, the dynamism of technical change recovered slightly. The wage share held fairly steady throughout the period. The rate of profit dropped between 1952 and 1991 before rising slightly from 1991 to 2008. The net capital accumulation rate contracted after 1975 because of the decline in the rates of profit and investment. Between 2004 and 2008, the net capital accumulation rate increased. Rio Grande do Sul, Brazil. aam@pucrs.br

Melody de Campos Soares Porsse is an adjunct professor at the Department of General and Applied Administration of the Federal University of Paraná, Brazil. msporsse@gmail.com 


\section{I}

\section{Introduction}

Brazil has gone through two wholly distinct phases of economic growth in the past 60 years. Between 1952 and 1980 , the country had one of the world's most dynamic economies, with a gross domestic product (GDP) growth rate of over 7\% a year. Between the end of the Second World War and 1980, growth was driven by the industrial sector in a framework of State-led import substitution industrialization. This industrialization process began to erode in 1973, when the "golden age" of the Brazilian economy started to enter into crisis because of the progressive deterioration of profitability and capital accumulation conditions.

In the second phase, from 1980 to 2003, growth dropped to $2 \%$, a decline of some 5 percentage points. Thus, the Brazilian economy was extremely weak in the 1980s, the so-called lost decade, and the 1990s. Corrected for the economic cycle, Brazilian GDP growth was $2.2 \%$ a year between 1980 and 1990 and $2.3 \%$ between 1990 and 2003. This contrasts with the major political shifts (redemocratization and the enactment of the federal Constitution in 1988) and economic changes that took place over the period. Economically, the most important changes were trade and financial opening, the control of inflation under the 1994 Real Plan, privatization and a reduction of the State's role in economic activity, and the adoption of the inflation targeting programme in 1999. The economic changes of the early 1990s put an end to import substitution industrialization in the country.

The international economy also underwent large institutional and technological changes after 1980. Institutional reforms aimed to make the market the primary mechanism for resource allocation once again, thus reducing the role of the State in this process, while the technology pattern was altered by new information and communication technologies (ICTs) that increased labour and capital productivity, especially when combined with organizational changes within firms. Globalization, meanwhile, meant an increasing flow of goods and capital between countries.

Technical progress is the main factor in a country's growth. The classical authors, Smith and Ricardo, together with Marx, pioneered research into the incorporation of technical progress into an economy and the long-term evolution of productivity. Smith studied the effects of the division of labour on productivity. Ricardo, in his chapter on machinery, analysed the income distribution and employment effects of replacing labour with capital. Marx associated analysis of capitalist development with the pattern of technical change. In Marx's view, production methods are being constantly altered in capitalism by the introduction of technical innovations to obtain a super-profit. Marx thought that the struggle between capitalists and workers over value added created a systematic incentive for a labour-saving and capitalusing bias in technical change.

According to Marx's analysis, mechanization is the typical form taken by technical change in capitalist economies, and increases in labour productivity are achieved by reducing capital productivity, with the resultant fall in the rate of profit if income distribution holds steady. Foley and Michl (1999) use the term "Marx-biased technical progress" for labour-saving, capital-using technical change. This contrasts with Harrod-neutral technical change, which is labour-saving but neither capital-using nor capital-saving. Marx-biased technical change also differs from Solow-neutral technical progress, which is neither labour-using nor labour-saving but is capital-saving, and from Hicks-neutral technical progress, which is both labour- and capital-saving.

The present study investigates patterns of technical change in the Brazilian economy between 1952 and 2008 and the relationship between these patterns and the country's growth. Patterns of technical change are analysed using the growth-distribution schedule, a straight line that shows labour productivity at the intersection with the Y-axis and capital productivity at the intersection with the $\mathrm{X}$-axis. The growth-distribution schedule is based on the Sraffa (1960) wage-profit curve and can be used to identify patterns of technical change over time.

The paper is organized as follows. After this Introduction, section II presents a system for studying technical change. Section III addresses technical change in the Brazilian economy from 1952 to 2008. Section IV discusses profitability, distribution and technical change. Section V focuses on capital accumulation and technical change. Lastly, section VI offers some final considerations. 


\section{II}

\section{A system for studying and representing technical change}

For the purposes of studying technical change, the economy is treated as producing just one good using capital and labour. The production technique is represented by the growth-distribution schedule. Among the studies employing this schedule to analyse the simultaneous behaviour of labour and capital productivity are Foley and Michl (1999), Foley and Marquetti (1997 and 1999), Marquetti (2002), Ferretti (2008) and Felipe, Laviña and Fan (2008).

For a given year, $X$ is GDP, $K$ is the net stock of non-residential fixed assets measured in the same unit as GDP, $C$ is aggregate consumption including all income other than gross investment, $I$ is gross investment, $D$ is depreciation, $N$ is the number of workers employed, $W$ is total worker compensation, $Z=X-W$ is gross profit and $R=Z-D$ net profit, and $Y=X-D$ is net output.

When countries' performance over time is being studied, it is preferable to express absolute measures in terms of ratios. Thus, $x=X / N$ is GDP per worker or labour productivity, $k=K / N$ is capital per worker or capital intensity, $w=W / N$ is the average real wage, $c=C / N$ is social consumption per worker and $i=I / N$ is investment per worker. Other variables are expressed in terms of capital stock: $p=X / K=x / k$ is output per unit of capital or capital productivity, $v=Z / K=z / k$ is the gross rate of profit and $r=v-d$ the net rate of profit, $g_{K}+d=I / K$ is the rate of capital accumulation, i.e., the ratio between gross investment and the capital stock, and $d=D / K$ is the depreciation rate. The growth rate of any variable, e.g., labour productivity, is denominated $g_{x}=\Delta x / x$, while $g_{p}$ is the capital productivity growth rate. The profit share of national income is $\pi=z / x$ and the wage share is $1-\pi=w / x$.

The growth-distribution schedule (see figure 1) is a way of representing national accounts components for a given period. For expenditure, the point $\left(g_{K}+d\right.$, $c$ ) shows the allocation of labour productivity between investment and consumption, $x=c+i=c+g_{k} k+d k=$ $c+\left(g_{K}+d\right) \mathrm{k}$. When the totality of output is invested, the capital accumulation rate takes the highest possible value, which is equal to capital productivity. Again, social consumption per worker is equal to labour productivity when the totality of output is consumed. As for income, the point $(r+d, w)$ shows the allocation of labour productivity between profits and wages, $x=w+z=w$ $+r k+d k=w+(r+d) k$. The maximum rate of profit, when all output takes the form of profit, is equal to capital productivity. In turn, the maximum wage, when the totality of output takes the form of wages, equals labour productivity.

Technology consists of all known production techniques. Each production technique is described in terms of labour productivity, capital productivity and the rate of depreciation. The pattern of technical change is analysed with reference to the combination of changes in labour and capital productivity. Technical change is labour-saving if it increases labour productivity and labour-using if it decreases it. Technical change is capital-saving if it increases capital productivity and capital-using if it decreases it. Consequently, it is possible to analyse the different types of technical progress over a given period by observing the movements in the growth-distribution schedule.

The literature distinguishes three types of technical progress. Harrod-neutral or pure labour-saving technical progress occurs when labour productivity rises while capital productivity remains unchanged. This pattern is represented by a shift in the growth-distribution schedule from technique $\mathrm{B}$ to technique $\mathrm{C}$ in figure 2 . Solow-neutral or pure capital-saving technical progress occurs when capital productivity rises while labour productivity remains unchanged, and is represented by a shift in the growth-distribution schedule from technique A to technique B. Hicks-neutral technical progress, which is both capital- and labour-saving, occurs when labour productivity grows at the same speed as capital productivity. This pattern is represented by a parallel shift in the growth-distribution schedule from technique A to technique $\mathrm{C}$, with the ratio between capital and labour remaining unchanged. 
FIGURE 1

The growth-distribution schedule

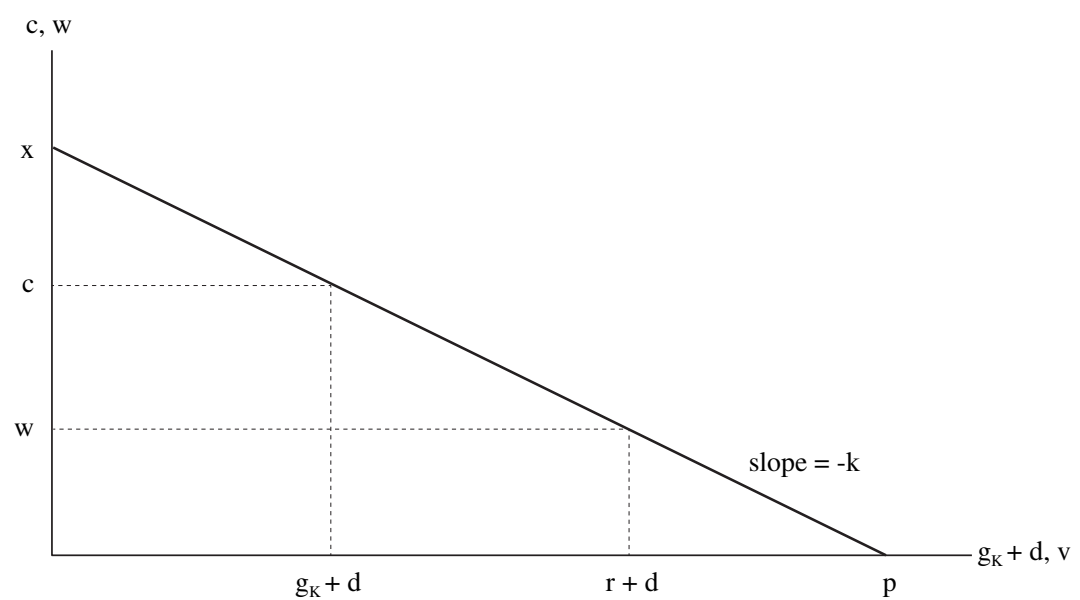

Source: D. Foley and T. Michl, Growth and Distribution, Cambridge, Massachusetts, Harvard University Press, 1999.

Note: $x$ is labour productivity, $k$ is capital intensity, $w$ is the average real wage, $c$ is social consumption per worker, $p$ is capital productivity, $v$ is the gross rate of profit, $r$ is the net rate of profit, $g_{k}+d$ is the rate of capital accumulation and $d$ is the rate of depreciation.

FIGURE 2

Conceptions of neutral technical change and movements in the growth-distribution schedule



Source: A. Marquetti, "Progresso técnico, distribuição e crescimento na economia brasileira: 1955-1998", Estudos econômicos, vol. 32, No. 1, São Paulo, University of São Paulo, 2002.

Note: $\mathrm{w}$ is the average real wage, $\mathrm{c}$ is social consumption per worker and $\mathrm{v}$ is the gross rate of profit. Harrod-neutral technical progress is represented by a shift in the growth-distribution schedule from technique A to technique B. Solow-neutral technical progress is indicated by a shift from technique $\mathrm{B}$ to technique $\mathrm{C}$. Hicks-neutral technical progress is represented by a shift from technique $\mathrm{A}$ to technique $\mathrm{C}$, with the ratio between capital and labour remaining unchanged.

In turn, Marx-biased technical progress entails rising labour productivity and declining capital productivity, as shown in figure 3. According to Marx, the struggle between capitalists and workers over value added creates a powerful incentive for technical change to follow a labour-saving and capital-using pattern where growing use of machinery and equipment replaces the labour of human beings. On this view, mechanization is the pattern of technical change in a capitalist economy, with rising labour productivity and falling capital productivity. Foley and Michl (1999) call this type of technical change Marx-biased technical change. Assuming a constant functional income distribution, the rate of profit falls if technical progress is Marx-biased, and as a result the capital accumulation and economic growth rates decline as well. 
FIGURE 3



Source: A. Marquetti, "Progresso técnico, distribuição e crescimento na economia brasileira: 1955-1998", Estudos econômicos, vol. 32, No. 1, São Paulo, University of São Paulo, 2002.

Note: $x$ is labour productivity, $w$ is the average real wage, $c$ is social consumption per worker, $p$ is capital productivity, $v$ is the gross rate of profit, $r$ is the net rate of profit and $d$ is the rate of depreciation.

With the Marx-biased pattern of technical progress, accordingly, the following long-run trends are predicted:

(i) rising labour productivity, falling capital productivity and increasing capital intensity;

(ii) decline in the rate of profit, with the wage share holding fairly steady;

(iii) rising real wages;

(iv) reduction in the rate of capital accumulation;

(v) higher output and employment.

As Duménil and Lévy (2003) point out, the historical trends are clearly interrelated and involve different aspects of economic theory. Figure 4 provides a very simplified illustration of the main relationships between the variables. The technique used and the distribution of income determine the rate of profit. The distribution of income also affects capitalists' saving and investment decisions. The rate of profit, assuming that some portion of profit is saved and invested, determines capital accumulation. The rate of profit also influences the choice of technique. A new technique will be adopted if the expected profitability, calculated on current wages, is higher than the existing rate of profit. Depending on the technique of production employed, capital accumulation gives rise to a given output and employment growth rate. In turn, growth affects the distribution of income between profits and wages. The various patterns of technical change display different long-run trends.

FIGURE 4

Relationships of determination in a growth model

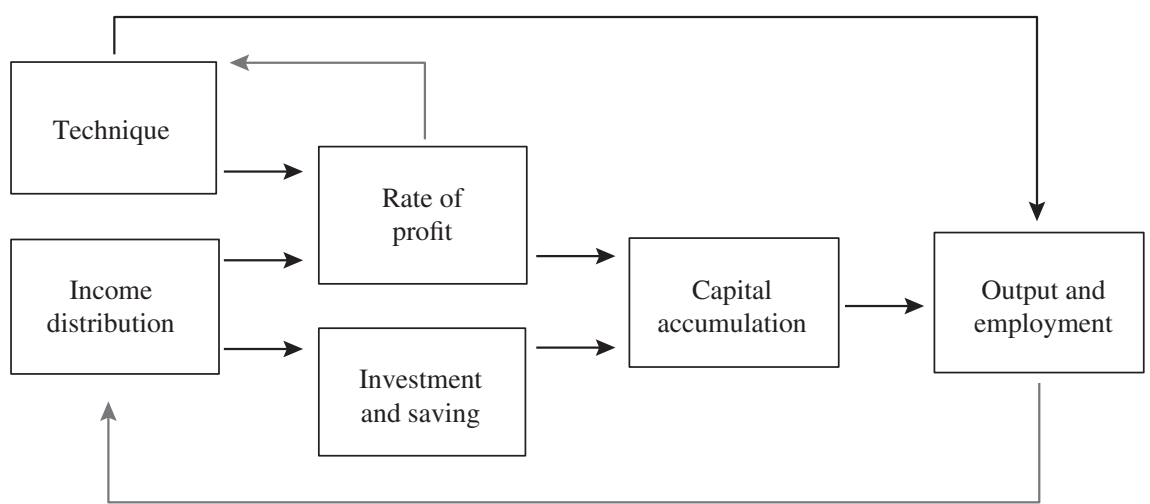

Source: prepared by the authors on the basis of G. Duménil and D. Lévy, "Technology and distribution: historical trajectories a la Marx", Journal of Economic Behavior \& Organization, vol. 52, No. 2, Amsterdam, Elsevier, 2003. 


\section{III \\ Technical change in the Brazilian economy between 1952 and 2008}

Figure 5 shows growth-distribution schedules in the Brazilian economy between 1952 and 2008. Labour and capital productivity were corrected for the business cycle using a local regression, a non-parametric method that applies smoothing to estimate curves and surfaces (Loader, 1999). The annex provides information on the sources of the database and the methodology employed to calculate the variables used in this article. A rise in labour productivity and a decline in capital productivity can be observed over the period studied. The pattern of technical progress was Marx-biased, as labour productivity grew by $2.25 \%$ a year between 1952 and 2008, while capital productivity fell by $1.48 \%$ a year.

Nonetheless, there were three phases in the dynamism of technical progress in the Brazilian economy (see figure 6). The first was the period from 1952 to 1975, when labour productivity growth was $4.45 \%$ and capital productivity declined by $1.93 \%$ a year. This phase was the "golden age" of capitalist development, with the Brazilian economy expanding at a rate of over 7\% a year. During this period, economic growth was led by the industrial sector via import substitution industrialization. The GDP share of industry at factor cost rose from $25 \%$ in 1952 to $43.3 \%$ in 1975 .

During the second phase, between 1975 and 1991, labour productivity grew by $0.71 \%$ a year and capital productivity fell by $2.99 \%$ a year. Brazil suffered the consequences of the ending of the "golden age" and the productivity decline experienced by a number of developed countries in the 1970s and 1980s. The economic growth rate remained high between 1975 and 1980, owing to the second National Development Plan. This plan was a response to the international crisis and was designed to stimulate the production of basic inputs, capital goods and

FIGURE 5

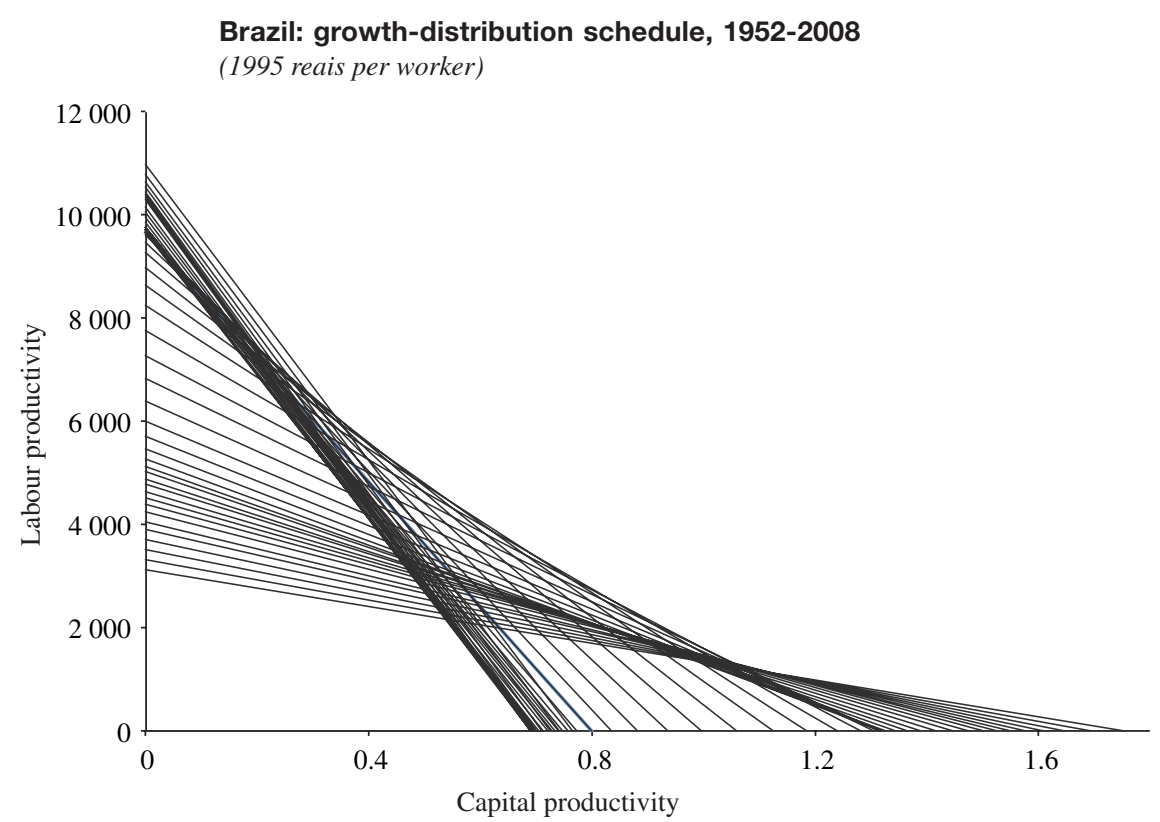

Source: Brazilian Geographical and Statistical Institute (IBGE), Sistema de Contas Nacionais - Brasil 2004/2008, Rio de Janeiro, CD-ROM, 2010; Estatísticas do século XX, Rio de Janeiro, CD-ROM, 2003; and Estatísticas históricas do Brasil: séries econômicas, demográficas e sociais de 1550 a 1988, Rio de Janeiro, Brazilian Geographical and Statistical Institute Foundation, 1990; A. Heston, R. Summers and B. Aten, "Penn World Table Version 6.2", Center for International Comparisons of Production, Income and Prices, 2006 [online] http://pwt. econ.upenn.edu8; A. Marquetti, "Estimativa do estoque de riqueza tangível no Brasil, 1950-1998”, Nova Economia, vol. 10, No. 2, Belo Horizonte, Federal University of Minas Gerais, 2000. 


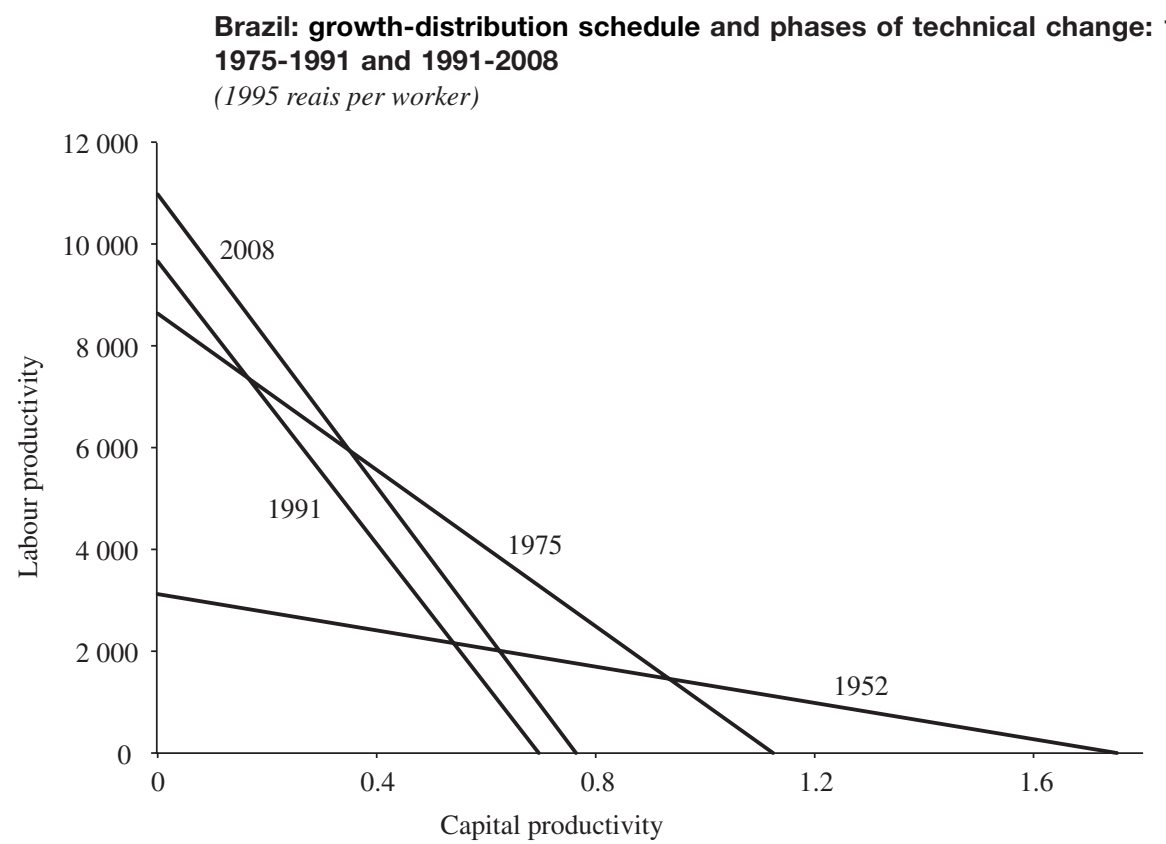

Source: Brazilian Geographical and Statistical Institute (IBGE), Sistema de Contas Nacionais - Brasil 2004/2008, Rio de Janeiro, CD-ROM, 2010; Estatísticas do século XX, Rio de Janeiro, CD-ROM, 2003; and Estatísticas históricas do Brasil: séries econômicas, demográficas e sociais de 1550 a 1988, Rio de Janeiro, Brazilian Geographical and Statistical Institute Foundation, 1990; A. Heston, R. Summers and B. Aten, "Penn World Table Version 6.2", Center for International Comparisons of Production, Income and Prices, 2006 [online] http://pwt. econ.upenn.edu8; A. Marquetti, "Estimativa do estoque de riqueza tangível no Brasil, 1950-1998", Nova Economia, vol. 10, No. 2, Belo Horizonte, Federal University of Minas Gerais, 2000.

energy. Its inability to sustain the dynamism of technical progress in the Brazilian economy was at the root of the crisis in the import substitution industrialization model. Annual growth dropped to $2 \%$ in the 1980 s. The industry share of GDP at factor cost peaked in 1985 and fell back to $36.6 \%$ in 1991. The deindustrialization of the Brazilian economy began during this phase.

Lastly, during the third phase, which began in 1991 and ended in 2008, labour and capital productivity grew by $0.75 \%$ and $0.55 \%$ a year, respectively. There was a significant change in the trajectory of capital productivity, which rose as a result of the adoption of new ICTs. This phase represented a new pattern of technical progress, termed input-saving technical change, where labour productivity growth is higher than capital productivity growth and the ratio of capital to labour increases.

In the late 1980s and early 1990s, import substitution industrialization was replaced by a new model, following the Washington Consensus (Williamson, 1992). The reforms carried out included the adoption of a new form of international integration involving trade and financial liberalization and the start of privatization. In consequence, Brazil began to receive a new flow of external resources that made it possible to launch the Real Plan in 1994. The Real Plan tied the real to the dollar and was very successful in reducing inflation, which dropped from $1,996 \%$ in 1993 to $8.3 \%$ in 1997, in values measured by the GDP deflator. The Brazilian economy grew by $2.7 \%$ a year from 1991 to 2003 and by $4.5 \%$ a year from 2003 to 2008 . Meanwhile, the industry share of GDP at basic prices fell to $27.9 \%$.

The three phases in the dynamism of technical change can also be seen in figure 7, which presents the evolution of labour productivity in the Brazilian economy between 1952 and 2008. Figure 7 shows rapid labour productivity growth up to the mid-1970s followed by stagnation until the 1990s, when labour productivity began rising again, albeit at lower rates than in the first phase. After 2004, with higher economic growth, labour productivity grew rapidly, although more data are needed to determine how much of this acceleration was due to a new phase of dynamism in technical change and how much to the business cycle.

Two significant aspects of the findings on the evolution of technical change in the Brazilian economy should be highlighted. First, there is a correspondence 
FIGURE 7



Source: Brazilian Geographical and Statistical Institute (IBGE), Sistema de Contas Nacionais - Brasil 2004/2008, Rio de Janeiro, CD-ROM, 2010; Estatísticas do século XX, Rio de Janeiro, CD-ROM, 2003; and Estatísticas históricas do Brasil: séries econômicas, demográficas e sociais de 1550 a 1988, Rio de Janeiro, Brazilian Geographical and Statistical Institute Foundation, 1990; A. Heston, R. Summers and B. Aten, "Penn World Table Version 6.2", Center for International Comparisons of Production, Income and Prices, 2006 [online] http://pwt. econ.upenn.edu8; A. Marquetti, "Estimativa do estoque de riqueza tangível no Brasil, 1950-1998", Nova Economia, vol. 10, No. 2, Belo Horizonte, Federal University of Minas Gerais, 2000.

between the different phases of technical change and the performance of the Brazilian economy. The Marxbiased pattern of technical progress arose during import substitution industrialization. The literature states that this is the typical pattern in less developed countries that have succeeded in catching up with the leading countries (Foley and Michl, 1999; Marquetti, 2003). Second, the last two phases of technical change in the Brazilian economy were similar to those in the United States (Duménil and Lévy, 2010). Technical change is due to a historical process whereby a country is able to invent new production methods or benefit from the transfer of techniques developed in other countries. Late-industrializing countries usually adopt techniques developed in the central country. The new techniques are not a public good, and therefore involve an acquisition cost and delays in implementation in less developed countries. They also require access to machinery and equipment, workforce education and a period of learning by firms and workers. However, using techniques developed in the leading country is easier and faster than discovering new ones.

\section{IV}

\section{Profitability, distribution and technical progress}

According to the classical-Marxian approach, the main driver of technical change is profitability. On this view, individual capitalists would adopt technical changes that reduced production costs at current prices and wages to obtain an above-average rate of profit by selling their products at prices set by less technically efficient competitors. However, it is the struggle between capital and labour over the distribution of value added that determines the form taken by technical change in capitalist society. Mechanization replaces human labour 
with machinery and equipment in the production process, increasing labour productivity. Okishio (1961) showed that, if real wages remained unchanged, the rate of profit tended to rise even if technical progress was Marx-biased.

The rate of profit is measured by the ratio between the total profits generated in a period and the fixed capital invested in the production process. It should be recalled that only a portion of total profits is appropriated by the capitalists. Other portions of the value added are appropriated by unproductive workers, the State and international value transfer. Duménil and Lévy (1993) have analysed the different ways of calculating the rate of profit.

In the present study, the rate of profit has been calculated as follows:

$$
v=Z / K=(Z / X) /(K / X)=\pi p=(1-w / x) p
$$

where $\pi$ is the profit share, $\mathrm{p}$ is capital productivity, $\mathrm{w}$ is the average real wage and $\mathrm{x}$ is labour productivity. The average real wage is deflated by the GDP deflator and represents the cost of a worker from the capitalist's point of view. The evolution of the rate of profit depends on two factors: functional income distribution and capital productivity. In turn, functional income distribution is determined by the evolution of the average real wage relative to labour productivity. The profits portion rises, as therefore does the rate of profit, when labour productivity grows by more than the average wage.

Figure 8 shows the path of the net rate of profit at current prices and at constant 1995 prices in the Brazilian economy during the period of study. A downward trend in both measures can be observed between 1952 and the early 1990s, when profitability increased slightly. The 1952-1990 period can be divided into two stages. In the first, from 1952 to 1973 , there was rapid industrialization in the $1950 \mathrm{~s}$, followed by political struggles in the early 1960s that culminated in the 1964 military coup. The political and economic changes that took place under the military dictatorship account for some of the increase in the rate of profit from the mid-1960s to 1973. In the second stage, from 1973 to 1990 , this rate dropped sharply, and falling profitability was one of the determinants of the structural crisis in the Brazilian economy. This period was characterized by the second National Development Plan, which presented a high level of capital accumulation and a rapid build-up of foreign debt that culminated in the debt crisis, high inflation and low growth of the 1980s.

The rate of profit increased slightly between 1990 and 2008. This phase corresponds to the period of neoliberalism in the Brazilian economy between 1990 and 2003 , followed by a period in which international conditions favourable to the country combined with the restoration of the State's role in the formulation and implementation of development policy between 2003 and 2008.

Movements in the rate of profit are explained by alterations in functional income distribution or capital productivity. Figure 9.A shows that the profits portion held fairly steady throughout the period studied, averaging $57.8 \%$ of GDP. Functional income distribution favoured workers in the periods of greatest political agitation, such as the late 1950s and early 1960s, as well as during the political liberalization of the second half of the $1970 \mathrm{~s}$ and early 1980s and in the years of highest inflation, especially the late 1980s and early 1990s.

On the other hand, the profit share increased from the start of the military dictatorship in 1964 until the socalled Brazilian miracle of 1968-1973. After bottoming out at $50.5 \%$ of GDP in 1993 , its lowest observed value, the profit share rose rapidly, peaking at $60.7 \%$ in 2004 . This change was apparently connected with the effects of neoliberal reforms and macroeconomic policies relating to employment and wages, which strengthened the political power of the capitalist class. Figure 9.B reveals that the average real wage tracked labour productivity, except during the 1991-2004 period.

Figure 10 presents the evolution of capital productivity, measured at constant 1995 prices and current prices. Much as with the rate of profit, there were three phases in the path of capital productivity: a phase of slight decline from 1952 to 1973 , followed by a rapid drop between 1973 and 1990 and a moderate rise between 1990 and 2008. However, capital productivity stood at much the same level in 2008 as in the early 1980s. The third phase represents a long-term shift in the evolution of capital productivity in Brazil, which could reflect the adoption of ICT-linked innovations. It can be seen that the long-run evolution of the rate of profit has been determined mainly by the evolution of capital productivity, which is a technological factor.

The difference between the net rate of profit as measured at current and at constant prices is due to the rise in the capital goods price deflator relative to the GDP price deflator, as shown in figure 11. A rise in this index during the 1950s and early 1960s was followed by a period of stability until the late 1970 s, when the relative prices of capital goods climbed again, peaking in the late 1980s. The relative price of capital goods in the Brazilian economy then stabilized from the early 1990s until 2008. 
FIGURE 8

Brazil: net rate of profit, 1952-2008

(Percentages)

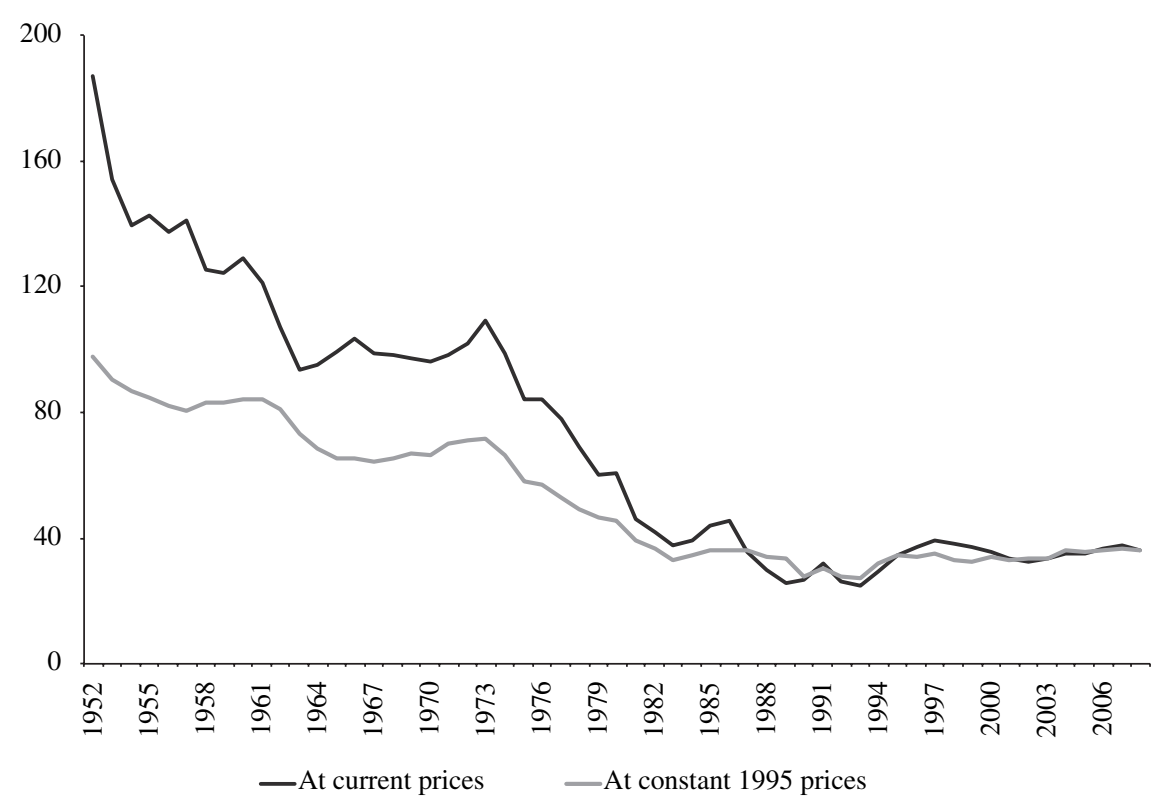

Source: Brazilian Geographical and Statistical Institute (IBGE), Sistema de Contas Nacionais - Brasil 2004/2008, Rio de Janeiro, CD-ROM, 2010; Estatísticas do século XX, Rio de Janeiro, CD-ROM, 2003; and Estatísticas históricas do Brasil: séries econômicas, demográficas e sociais de 1550 a 1988, Rio de Janeiro, Brazilian Geographical and Statistical Institute Foundation, 1990; A. Marquetti, "Estimativa do estoque de riqueza tangível no Brasil, 1950-1998”, Nova Economia, vol. 10, No. 2, Belo Horizonte, Federal University of Minas Gerais, 2000.

FIGURE 9

Brazil: profit share and evolution of labour productivity and real wages, 1952-2008

A. Profit share, $1952-2008$

(Percentages of GDP)

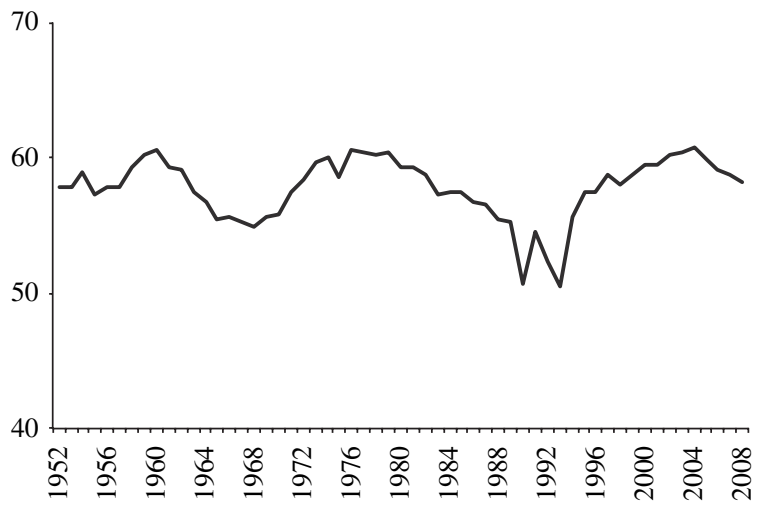

B. Labour productivity and real wages, 1952-2008 (Percentages)

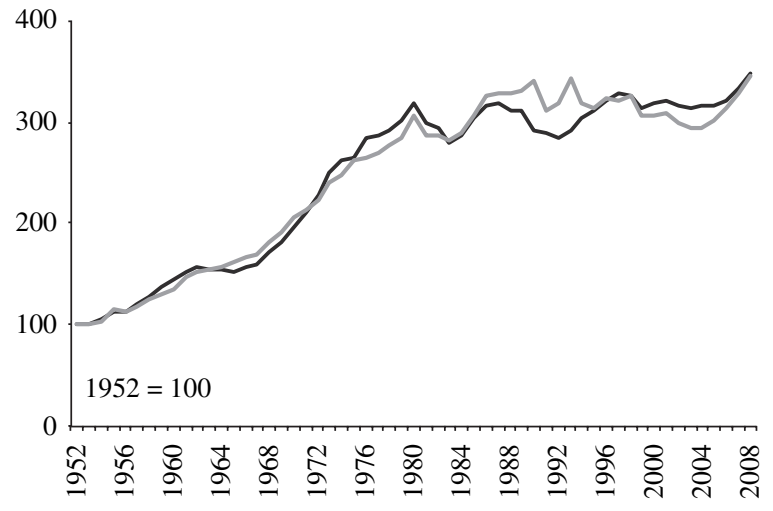

Labour productivity $\longrightarrow$ Average real wage

Source: Brazilian Geographical and Statistical Institute (IBGE), Sistema de Contas Nacionais - Brasil 2004/2008, Rio de Janeiro, CD-ROM, 2010; Estatísticas do século XX, Rio de Janeiro, CD-ROM, 2003; and Estatísticas históricas do Brasil: séries econômicas, demográficas e sociais de 1550 a 1988, Rio de Janeiro, Brazilian Geographical and Statistical Institute Foundation, 1990; A. Heston, R. Summers and B. Aten, "Penn World Table Version 6.2", Center for International Comparisons of Production, Income and Prices, 2006 [online] http://pwt. econ.upenn.edu8. 
FIGURE 10

Brazil: capital productivity, 1952-2008

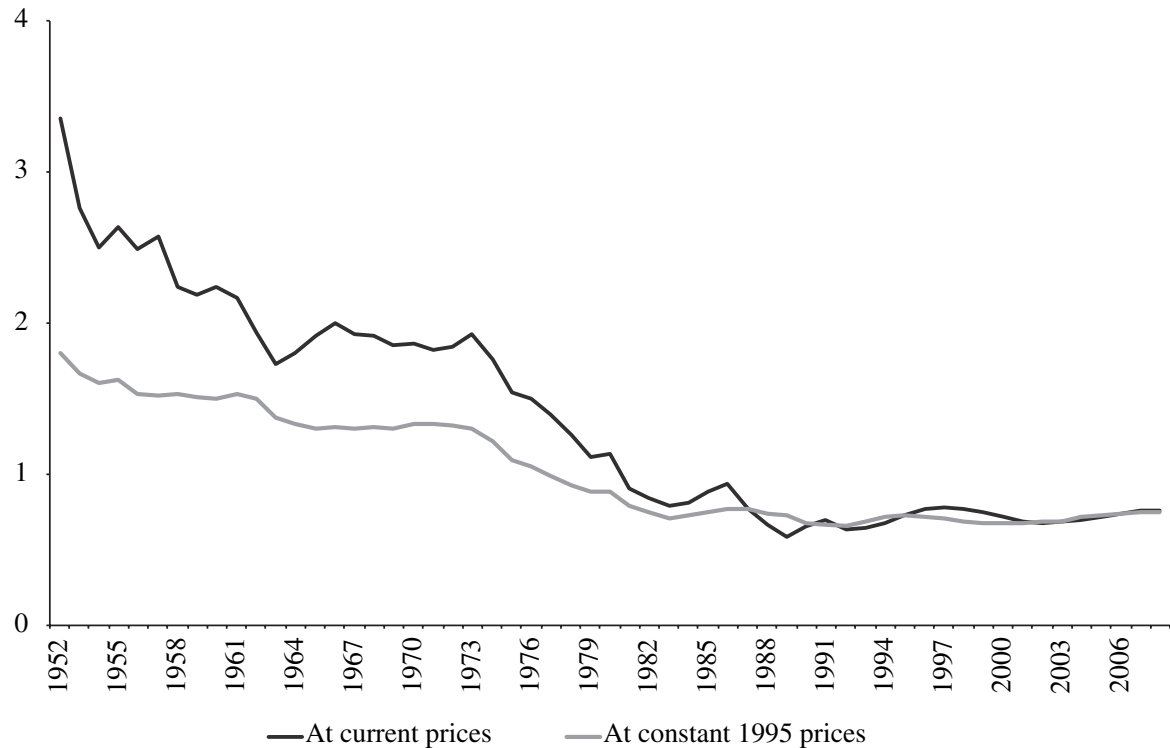

Source: Brazilian Geographical and Statistical Institute (IBGE), Sistema de Contas Nacionais - Brasil 2004/2008, Rio de Janeiro, CD-ROM, 2010; Estatísticas do século XX, Rio de Janeiro, CD-ROM, 2003; and Estatísticas históricas do Brasil: séries econômicas, demográficas e sociais de 1550 a 1988, Rio de Janeiro, Brazilian Geographical and Statistical Institute Foundation, 1990; A. Marquetti, "Estimativa do estoque de riqueza tangível no Brasil, 1950-1998", Nova Economia, vol. 10, No. 2, Belo Horizonte, Federal University of Minas Gerais, 2000.

FIGURE 11

Brazil: capital goods price deflator relative to the GDP deflator, 1952-2008 (Percentages)

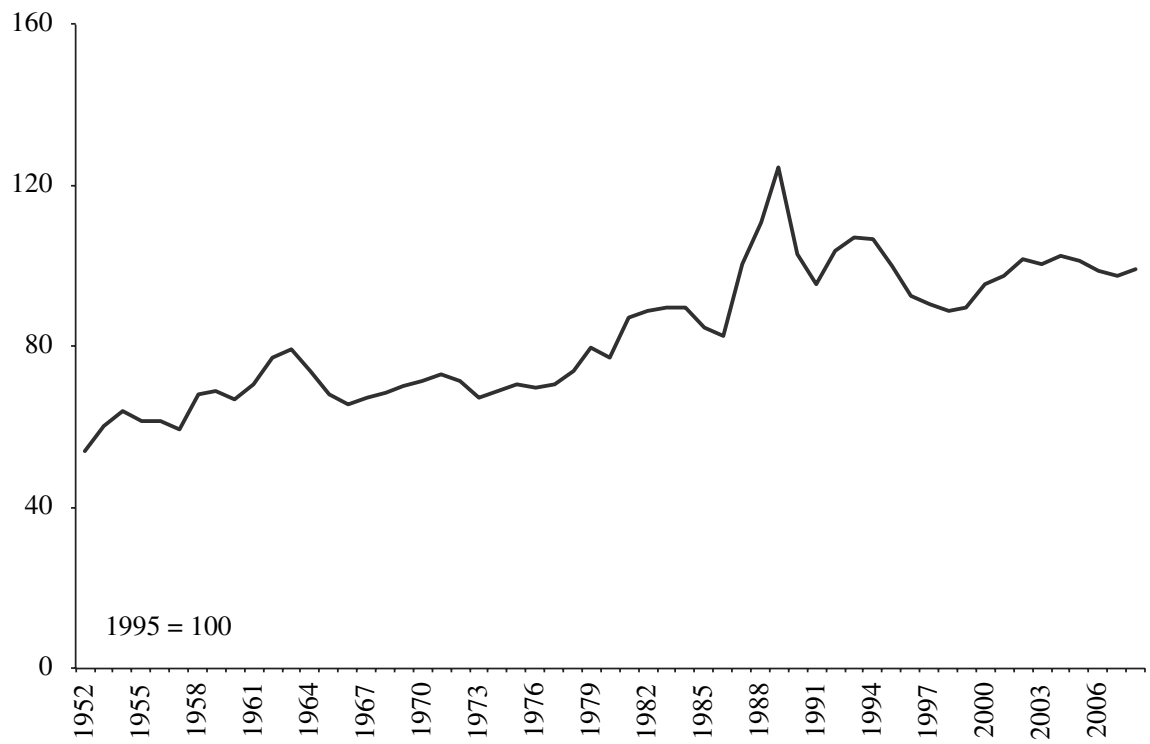

Source: Brazilian Geographical and Statistical Institute (IBGE), Sistema de Contas Nacionais - Brasil 2004/2008, Rio de Janeiro, CD-ROM, 2010; Estatísticas do século XX, Rio de Janeiro, CD-ROM, 2003; and Estatísticas históricas do Brasil: séries econômicas, demográficas e sociais de 1550 a 1988, Rio de Janeiro, Brazilian Geographical and Statistical Institute Foundation, 1990; A. Marquetti, "Estimativa do estoque de riqueza tangível no Brasil, 1950-1998", Nova Economia, vol. 10, No. 2, Belo Horizonte, Federal University of Minas Gerais, 2000. 


\section{V}

\section{Capital accumulation and technical progress}

Capital accumulation measures the speed at which the country is enlarging its stock of productive capital, which comprises non-residential buildings, machinery and equipment. Consequently, as long as labour is available, capital accumulation measures the speed at which the country's capacity for producing wealth is expanding. The net capital accumulation rate is determined by the rate of profit and the investment rate. If the pattern of technical progress is Marx-biased, the trend of the accumulation rate ought to be downward, tracking the decline of the rate of profit.

Figure 12 presents the capital accumulation rate in the Brazilian economy between 1952 and 2008. Three significant aspects of capital accumulation in Brazil can be observed. First, five cycles can be distinguished in the period of study, namely: 1955-1965, peaking in 1959; 1965-1983, peaking in 1975; 1983-1993, peaking in 1986; 1993-2003, peaking in 1997; and, lastly, the present cycle, which began in 2003. Second, the net accumulation rate shows a downward trend much like the one observed in the net rate of profit due to the Marx-biased pattern of technical change. The peaks (except that of 1975) and troughs of each successive cycle were lower than those of the previous one. Third, two different periods can be observed for the capital accumulation rate in Brazil. Between 1952 and the late 1970s, economic growth was led by the industrial sector, in the framework of an import substitution industrialization model. The Brazilian economy mechanized during that period. The rate of profit fell sharply in the second half of the 1970s and the early 1980s, and this marked the transition between the stage with a high capital accumulation rate in the Brazilian economy and the stage with a more subdued rate. From the early 1980s to the start of the 1990s, the low rate of accumulation was due to a combination of poor profitability and the external debt crisis. A neoliberal model was applied in Brazil from the early 1990s until 2003 but, despite higher profitability, the accumulation rate was low because of the fall in the investment rate.

FIGURE 12

Brazil: net capital accumulation rate, 1952-2008

(Percentages)

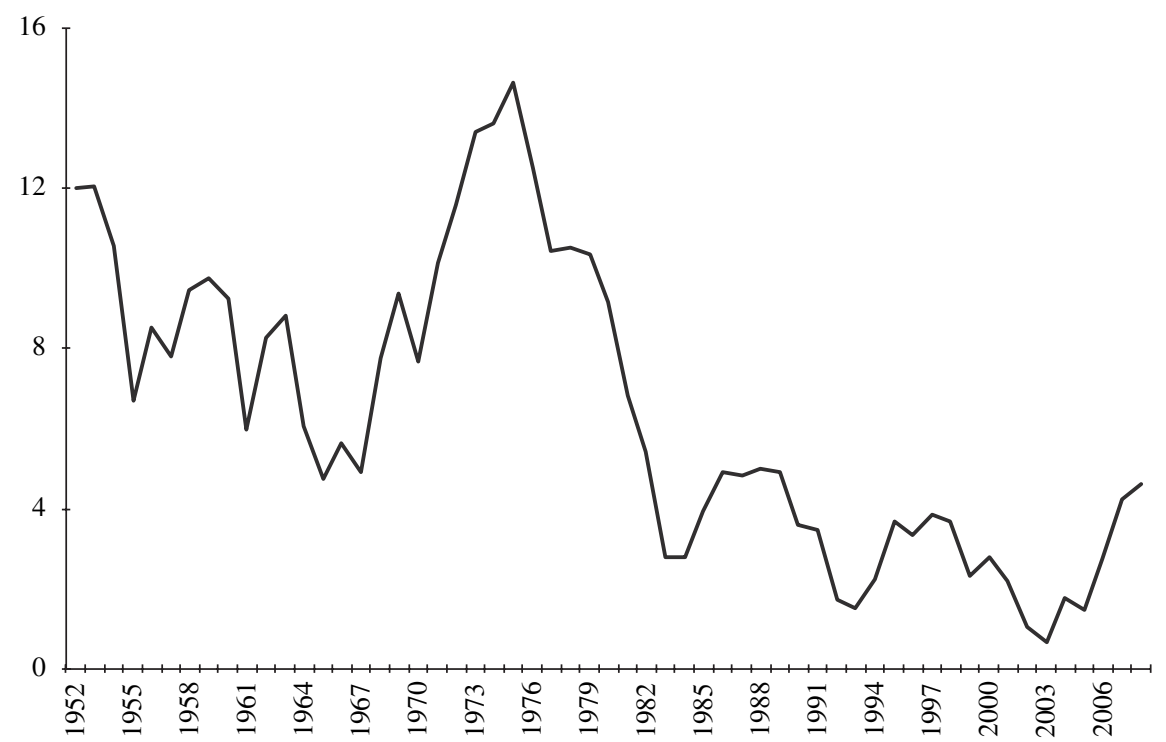

Source: Brazilian Geographical and Statistical Institute (IBGE), Sistema de Contas Nacionais - Brasil 2004/2008, Rio de Janeiro, CD-ROM, 2010; Estatísticas do século XX, Rio de Janeiro, CD-ROM, 2003; and Estatísticas históricas do Brasil: séries econômicas, demográficas e sociais de 1550 a 1988, Rio de Janeiro, Brazilian Geographical and Statistical Institute Foundation, 1990; A. Marquetti, "Estimativa do estoque de riqueza tangível no Brasil, 1950-1998”, Nova Economia, vol. 10, No. 2, Belo Horizonte, Federal University of Minas Gerais, 2000. 
Figure 13 shows the evolution of the capital accumulation rate and the net rate of profit between 1952 and 2008. The downward trend in the accumulation rate was similar to that observed in the net rate of profit, indicating a long-run relationship between these two variables. The drop in profitability caused by the decline in capital productivity was one of the factors responsible for the decline in the accumulation rate in the Brazilian economy. As indicated earlier, these are the long-run tendencies of the Marx-biased pattern of technical change.

The path of the capital accumulation rate and the net investment rate is shown in figure 14. Cyclical changes in the capital accumulation rate are strongly influenced by the net investment rate. The Goals Plan, which provided for a large increase in investment from 1956 to 1960 led by the public sector and State enterprises and with strong participation by external capital, yielded rapid investment growth.

The early 1960s was a time of great political upheaval, culminating in the 1964 military coup. After a series of institutional changes, investment recovered in the late 1960s. The net accumulation rate grew robustly during the so-called Brazilian economic miracle between 1968 and 1973, exceeding 12\% a year between 1974 and 1976. It should be noted that the investment rate peaked during the second National Development Plan, a time of sharply falling profitability. The high rate of investment was due to State leadership in the process, which was financed by external borrowing.

The 1980s were characterized by a decline in the net investment rate, and this continued through the 1990s and the early 2000s. This rate bottomed out in 2003 and then began to rise again.

The reduction in the accumulation rate in the Brazilian economy in 1975 is accounted for by the sharp fall in the rate of profit after 1973. In the 1980s, the accumulation rate also began to suffer the negative effects of the declining investment rate. The strategy adopted with the second National Development Plan resulted in higher external debt, exacerbating the country's financial fragility. The effects of the second oil crisis and, chiefly, the rise in international interest rates were very damaging to the Brazilian economy. The ability to generate wealth, as measured by the labour productivity growth rate, was necessary for the country to cope with future payments, but it barely increased relative to the rise in external debt and the likelihood of negative external shocks. The servicing of this debt meant a huge transfer of resources abroad in the 1980s, causing the net investment rate to decline.

FIGURE 13

Brazil: net capital accumulation rate and net rate of profit, 1952-2008

(Percentages)

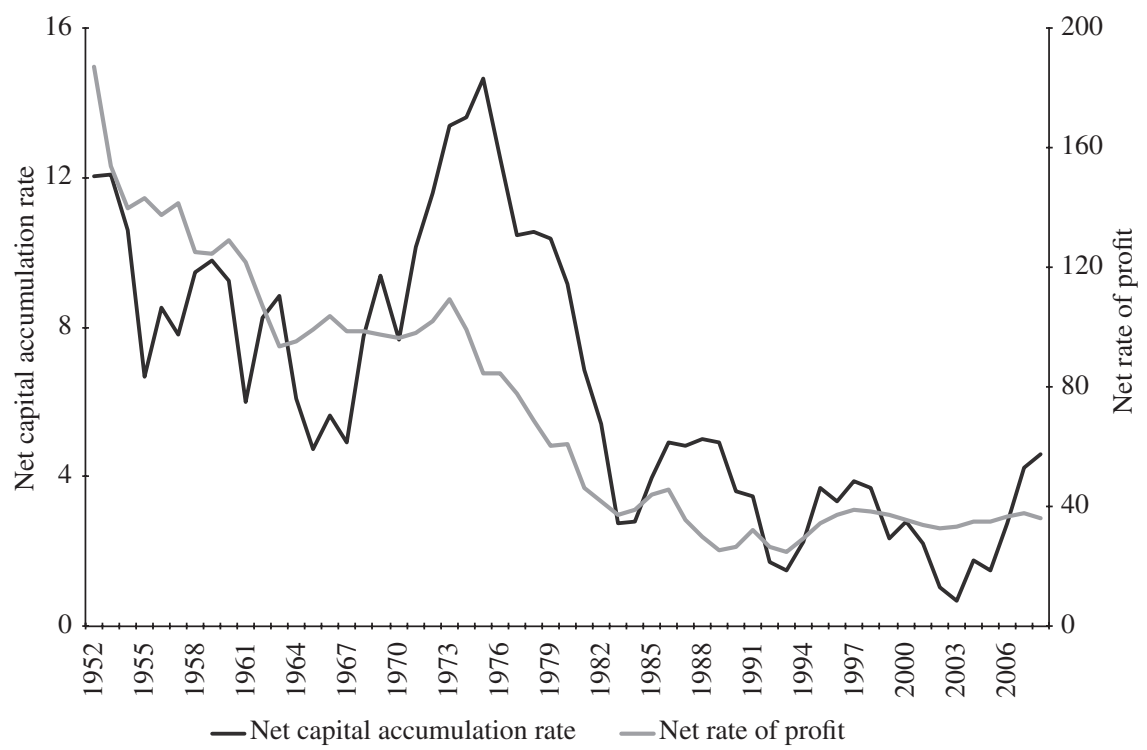

Source: Brazilian Geographical and Statistical Institute (IBGE), Sistema de Contas Nacionais - Brasil 2004/2008, Rio de Janeiro, CD-ROM, 2010; Estatísticas do século XX, Rio de Janeiro, CD-ROM, 2003; and Estatísticas históricas do Brasil: séries econômicas, demográficas e sociais de 1550 a 1988, Rio de Janeiro, Brazilian Geographical and Statistical Institute Foundation, 1990; A. Marquetti, "Estimativa do estoque de riqueza tangível no Brasil, 1950-1998”, Nova Economia, vol. 10, No. 2, Belo Horizonte, Federal University of Minas Gerais, 2000. 


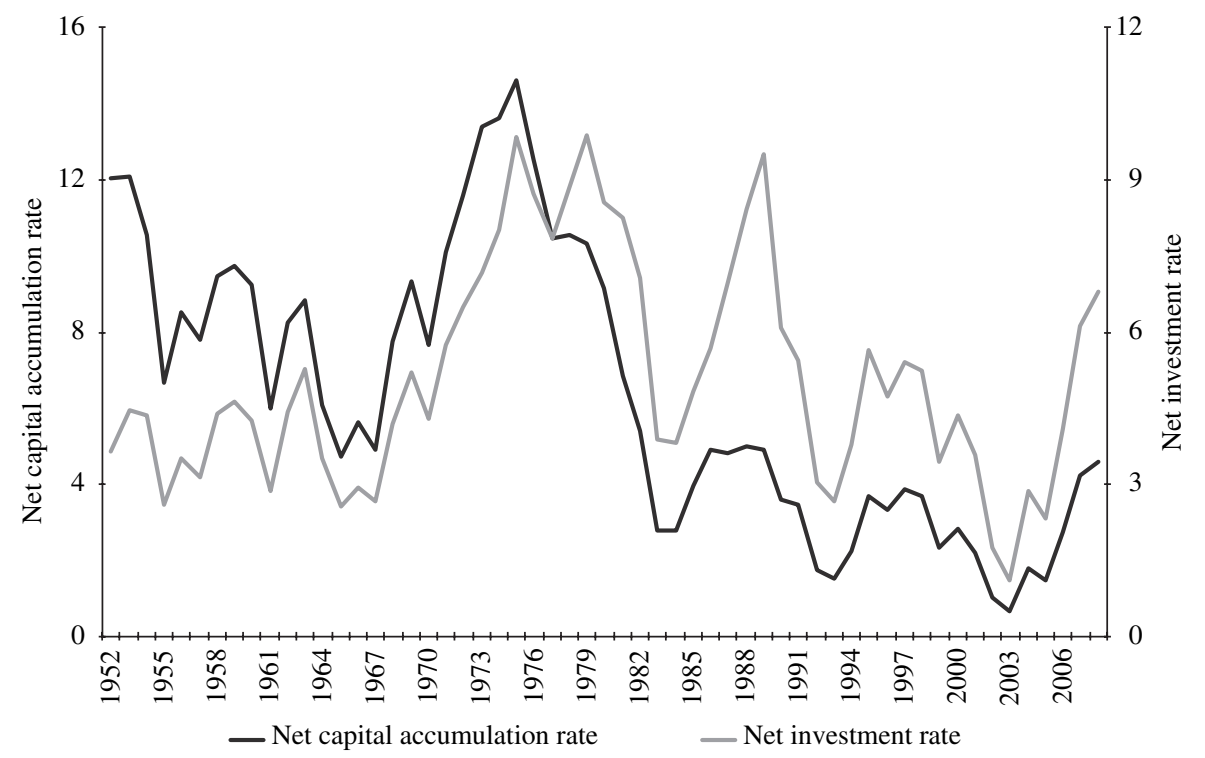

Source: Brazilian Geographical and Statistical Institute (IBGE), Sistema de Contas Nacionais - Brasil 2004/2008, Rio de Janeiro, CD-ROM, 2010; Estatísticas do século XX, Rio de Janeiro, CD-ROM, 2003; and Estatísticas históricas do Brasil: séries econômicas, demográficas e sociais de 1550 a 1988, Rio de Janeiro, Brazilian Geographical and Statistical Institute Foundation, 1990; A. Marquetti, "Estimativa do estoque de riqueza tangível no Brasil, 1950-1998”, Nova Economia, vol. 10, No. 2, Belo Horizonte, Federal University of Minas Gerais, 2000.

Moreover, concurrent increases in the domestic debt, the real interest rate in the domestic market and inflation associated with the indexation mechanism resulted in a transfer of resources from the productive sector to the financial sector. These factors, together with the fall in the rate of profit, account for the reduction in the accumulation rate in the Brazilian economy from the late 1970s onward. The origin of the Brazilian economic crisis lay in the slackening of technical progress in the mid-1970s. The decline in the net investment rate from the late 1970s worsened the situation, which was already having a negative effect on the accumulation rate.

This study endorses the analysis of the causes of Brazilian inflation in the late 1970s and early 1980s conducted by Celso Furtado in 1984. According to that author:

[...] the root cause of the inflation is the decrease in the productivity of the economic system [...] The average productivity of investments has traditionally been high in Brazil. To achieve a one per cent increase in domestic product it was only necessary to invest two per cent of this same product $[. .$.$] What has been occurring recently is$ a notable fall in productivity. Today, we need to invest four to six per cent of domestic product to achieve a one per cent increase in the product $[\ldots]$ the main reason [for this] is the lack of coordination of public investments, and of private investments induced by it (Furtado, 1984, pp. 7-8).

It is interesting to note that the downward trend in the capital accumulation rate and the net investment rate continued throughout the 1990 s, despite rising profitability. The so-called lost decade of the 1980s was a period of crisis and transition from the import substitution industrialization model to the neoliberal model. Neoliberalism represented the adoption of a "market-friendly" model of growth whereby the State's role in the economy was reduced, State firms were privatized, capital and labour markets were liberalized and there was greater international integration. This model's supporters believed that, by introducing neoliberal reforms, Brazil would benefit from globalization and receive a fresh inflow of international investment that would increase capital accumulation and productivity in the economy (Franco, 1998).

From 1990 onward, the Brazilian economy underwent a series of neoliberal reforms. They included the adoption of a new form of international integration via trade and financial liberalization (Cysne, 1998) and the privatization programme, involving sell-offs of firms in 
the petrochemical and metal ores sectors being sold off. External debt renegotiation under the Brady Plan enabled Brazil to return to the international financial market and build up sufficient reserves to launch the Real Plan in 1994. The Plan comprised two parts: a macroeconomic policy to control inflation and a programme of neoliberal reforms to stimulate growth.

High interest rates and Brazil's return to the international capital market allowed the currency to appreciate and inflation to fall to single-digit levels. After 1994, the privatization of public services began, with sell-offs of telecommunication, electricity and banking firms.

One of the main problems with the Real Plan was that it increased the external financial fragility of the Brazilian economy, and this, combined with the volatility of international capital, caused the real to depreciate in early 1999. The Brazilian crisis was preceded by a string of international upheavals that started with the 1994 Mexican crisis, followed by the 1997 Asian crisis and the 1998 crisis in the Russian Federation. The country's economic authorities responded to the crisis by adopting a policy that combined an inflation target, a primary fiscal surplus and a floating exchange rate. Monetary policy played a fundamental role in controlling the exchange rate via an interest rate high enough to attract international capital and thus keep inflation down to near the desired level.

With the Real Plan, Brazil fully adopted the neoliberal agenda. Although the policies successfully brought down inflation, they were unable to restore dynamism to the Brazilian economy. The net accumulation rate was very low, despite the shift in the pattern of technical change in the Brazilian economy, which meant only a limited recovery in profits. After picking up again between 1993 and 1997, the net investment rate fell again, bottoming out in 2003.

The net investment rate and the accumulation rate recovered from 2004 onward. The fundamental question is whether the recovery represented a cyclical change or a break from the period of low growth in the Brazilian economy lasting from 1980 to 2003. Initially, the country benefited from a rise in exports thanks to growth in international sales of commodities to China and India. In a second stage, however, investment expanded strongly thanks to the Growth Acceleration Programme. This is a programme whose main objective is to stimulate the country's economic growth through State action to promote and induce investment by the public sector and by State and private-sector firms. The net investment rate and the capital accumulation rate in 2007 and 2008 were the highest since 1990.

\section{VI}

\section{Final considerations}

Analysis of technical progress in the Brazilian economy has revealed that a Marx-biased labour-saving and capital-using pattern predominated in the period from 1952 to 2008. Since functional income distribution was fairly stable, the rate of profit in the Brazilian economy declined in the period studied.

This pattern was not uniform in all the years studied, however. Three phases of technical progress can be distinguished: 1952-1975, 1975-1991 and 1991-2008. The first phase, at the height of the import substitution industrialization strategy, saw rapid growth in the Brazilian economy, a $4.45 \%$ annual increase in labour productivity and an annual decline of $1.93 \%$ in capital productivity. During the second phase, marked by the crisis and the end of import substitution, the rate of profit and capital accumulation fell sharply. Labour productivity increased by just $0.71 \%$ a year and capital productivity fell by $3 \%$ a year. Lastly, the third phase involved a new pattern of technical progress, particularly where capital productivity was concerned, with labour productivity growing by $0.75 \%$ a year and capital productivity by $0.55 \%$.

The Brazilian crisis that began in the mid-1970s reproduced a situation that had already arisen in the developed economies and that entailed a sharp decline in capital productivity and stagnation of labour productivity in those countries. The drop in the rate of profit in the Brazilian economy from 1973 onward led to the capital accumulation rate decreasing, and with it the capacity of the Brazilian economy to achieve significant increases in labour productivity. The 1980s debt crisis aggravated the decline in the accumulation rate and the weak growth capacity of the Brazilian economy. From the late 1970s, there was also a sharp drop in the net investment rate. 
Growth in the Brazilian economy was moderate during the 1990s, despite the opportunities represented by the increased dynamism of technical change associated with the new ICTs and the increase in the rate of profit. This rise should have been accompanied by growing investment, but this did not happen. Investment did

ANNEX

Database and methodology

This appendix presents the information sources and procedure used to build the database employed in this article. The main difficulty in conducting long-run empirical studies of the Brazilian economy is to find a consistent way of organizing information. National accounts began to be published in Brazil in 1947. The last major methodological change in the System of National Accounts took place with the publication of Sistema de Contas Nacionais - Brasil, Referência 2000. The alterations were made to bring it more into line with the System of National Accounts 1993. In future, there will have to be further amendments to adapt the country's national accounts to the System of National Accounts 2008.

The data for real GDP and the GDP deflator were obtained from IBGE (1990) and IBGE (2003) for the 1952-1985 period. The data for 1995-2008 were taken from IBGE (2010). Owing to changes in methodology, 1995 GDP is $8.84 \%$ greater in IBGE (2010) than in IBGE (2003). The data for 1986-1994 were calculated by taking real GDP growth rates from IBGE (2003) and increasing them by distributing that $8.84 \%$ over the period. Thus, the data source for real GDP is IBGE (2003) for 1985 and IBGE (2010) for 1995. The differences between the series were adjusted right across the 1986-1994 period. A similar procedure was used for the other variables.

The number of workers for the 1995-2008 period was calculated from IBGE (2010). Census year data were also taken from IBGE (1990). The information needed to complete the years without data was taken from Heston, Summers and Atten (2006). It should be noted that IBGE (2003) gives the number of workers for the years from 1990 to 1995. not expand consistently until the Growth Acceleration Programme was implemented. Labour productivity grew by $2 \%$ a year and capital productivity by $1.9 \%$ between 2003 and 2008. When supply conditions are right, Keynesian policies can stimulate greater economic growth and higher productivity.

Worker wage and wage share data for 1995-2008 were taken from IBGE (2010) and, in the case of census years, from IBGE (2010). Mixed income is divided into two parts, with one being added to wages and the other to the operating surplus. In the years for which no information was available, the average wage was estimated econometrically.

The net stock of non-residential fixed capital was estimated using the perpetual inventory method. The source of information on gross fixed capital formation (GFCF) was IBGE (2003) from 1947 to 1985 and IBGE (2010) from 1995 to 2008. To connect the two series, a procedure similar to the one used to calculate GDP was employed for the years from 1986 to 1994 . The data source for the years prior to 1947 is Marquetti (2000). The perpetual inventory method employed in this study is similar to the one used by the Bureau of Economic Analysis. The rate of depreciation is calculated as $R / T$, where $R$ is the rate at which an asset value declines and $T$ is the lifespan of the asset. There are two main differences from the methodology of the Bureau of Economic Analysis. First, $R$ is taken as being equal to 2 , in line with the double declining balance depreciation method. Second, the asset is withdrawn when it reaches its average lifespan. Because of the enormous differences in gross capital formation in machinery and equipment and non-residential building between IBGE (2003) and IBGE (2010), the capital goods category consists of just one asset. The working life of this asset is 26 years. Fixed capital consumption is measured as the sum of the net fixed capital stock and GFCF at the start of the period, minus the net fixed capital stock at the end of the period. 


\section{Bibliography}

Cysne, R. (1998), "Aspectos macro e microeconômicos das reformas brasileiras", Ensaios Econômicos da EPGE, No. 328, Rio de Janeiro, Getulio Vargas Foundation.

Duménil, G. and D. Lévy (2010), “The classical-Marxian evolutionary model of technical change: application to historical tendencies", Handbook of Alternative Theories of Economic Growth, M. Setterfield (ed.), Aldershot, Edward Elgar.

(2004), Capital Resurgent. Roots of the Neoliberal Revolution, Cambridge, Harvard University Press.

(2003), "Technology and distribution: historical trajectories a la Marx", Journal of Economic Behavior \& Organization, vol. 52, No. 2, Amsterdam, Elsevier.

(1993), The Economics of the Profit Rate: Competition, Crises, and Historical Tendencies in Capitalism, Aldershot, Edward Elgar.

Felipe, J., E. Laviña and E. Fan (2008), “The diverging patterns of profitability, investment and growth of China and India during 1980-2003", World Development, vol. 36, No. 5, Amsterdam, Elsevier.

Ferretti, F. (2008), "Patterns of technical change: a geometrical analysis using the wage-profit rate schedule", International Review of Applied Economics, vol. 22, No. 5, Taylor \& Francis.

Foley, D. and A. Marquetti (1999), "Productivity, employment and growth in European integration", Metroeconomica, vol. 50, No. 3, Wiley.

(1997), "Economic growth from a classical perspective", Money, Growth, Distribution and Structural Change: Contemporaneous Analysis, J. Teixeira (ed.), Brasilia, Editora Universidade de Brasília.

Foley, D. and T. Michl (1999), Growth and Distribution, Cambridge, Harvard University Press.

Franco, G. (1998), "A inserção externa e o desenvolvimento", Revista de Economia Política, vol. 18, No. 3, July/September.
Furtado, C. (1984), No to Recession and Unemployment, London, The Eastern Press Ltd.

Heston, A., R. Summers and B. Aten (2006), "Penn World Table Version 6.2", Center for International Comparisons of Production, Income and Prices [online] http://pwt.econ. upenn.edu8.

IBGE (Brazilian Geographical and Statistical Institute) (2010), Sistema de Contas Nacionais - Brasil 2004/2008, Rio de Janeiro, CD-Rom.

(2003), Estatísticas do século XX, Rio de Janeiro, CD-Rom. (1990), Estatísticas históricas do Brasil: séries econômicas, demográficas e sociais de 1550 a 1988, Rio de Janeiro, Fundação Instituto Brasileiro de Geografia e Estatistica.

Loader, C. (1999), Local Regression and Likelihood, New York, Springer-Verlag.

Marquetti, A. (2003), "Analyzing historical and regional patterns of technical change from a classical-Marxian perspective", Journal of Economic Behavior \& Organization, vol. 52, No. 2, Amsterdam, Elsevier.

(2002), "Progresso técnico, distribuição e crescimento na economia brasileira: 1955-1998”, Estudos econômicos, vol. 32, No. 1, São Paulo, University of São Paulo.

(2000), "Estimativa do estoque de riqueza tangível no Brasil, 1950-1998", Nova Economia, vol. 10, No. 2, Belo Horizonte, Federal University of Minas Gerais.

Okishio, N. (1961), "Technical change and the rate of profit", Kobe University Economic Review, vol. 7, Hyogo, Kobe University.

Sraffa, P. (1960), Production of Commodities by Means of Commodities, Cambridge, Cambridge University Press.

Williamson, J. (1992), "Reformas políticas na América Latina na década de 80", Revista de Economia Política, vol. 12, No. 45, São Paulo. 